\title{
Toxicity of Small Leaf Piptadeniastrum africanum (Saw-Dust Pow- der) To African Catfish Clarias gariepinus, Adult
}

\author{
Ada Fidelis Bekeh*, Ayotunde Ezekiel Olatunji, Usang Patrick Bassey \\ Department of Fisheries and Aquatic Science, Cross River University of Technology, Calabar,Obubra Campus, Obubra Cross River \\ State, Nigeria
}

"Corresponding author: Ada Fidelis Bekeh, Department of Fisheries and Aquatic Science, Cross River University of Technology, Calabar, PMB 102 Obubra Campus. Obubra Cross River State. Nigeria. Tel: +234 09096417140; Email: fbekehada@yahoo. com

Citation: Bekeh AF, Ayotunde EO, Bassey UP (2017) Toxicity of Small Leaf Piptadeniastrumafricanum (Saw-Dust Powder) To African Catfish Clariasgariepinus, Adult. J Fish Aqua Dev: JFAD-116. DOI:10.29011/JFAD-116/100016

Received Date: : 25 July, 2017; Accepted Date: 15 August, 2017; Published Date: 23 August, 2017

\begin{abstract}
This work determines the toxicity of the aqueous extract of Piptadeniastrum africanumsaw-dust powder to Clarias gariepinusadult (mean body weight $86.01 \pm 12.10 \mathrm{~g}$ and length, $20.91 \pm 2.09 \mathrm{~cm}$ ). The $96 \mathrm{hrsLC} 50 \mathrm{is} 3.3 \mathrm{mg} / \mathrm{l}$ and the maximum admissible toxicant concentrations ranges between $0.33 \mathrm{mg} / 1-0.033 \mathrm{mg} / \mathrm{l}$, while the total mortality occurred in the concentration of $19.8 \mathrm{mg} / 1$ within $24 \mathrm{hrs}$ exposure period. Toxic reaction exhibited by the fish includes erratic movement, air gulping, loss of reflex, discolouration, molting, and haemorrhage. There were no significant changes in the water quality before, during and afterthe experiment, the result obtained before the test, during the test and after the test were found close to the physico -chemical parameters of the control. The haematological examination shows decrease in a number of cell counts WBC, RBC, Hb, $\mathrm{MCV}$, hematocrit lymphocytes with mean values $(1.61 \pm 4.01,1.23 \pm 0.09,5.13 \pm 0.67,1.40 \pm 18.30,17.80 \pm 2.88$ and $1.54 \pm 4.80)$ to $(1.70 \pm 10.29,1.55 \pm 0.07,6.20 \pm 0.10,1.40 \pm 3.30,21.77 \pm 0.40$ and $1.70 \pm 1.66)$. There was significant decrease in $\mathrm{MCH}, \mathrm{MCHC}$ and platelet with mean values $(40.43 \pm 2.93,28.97 \pm 1.89$ and $27.67 \pm 10.26)$ to $(39.93 \pm 1.00,28.50 \pm 0.10$ and $10.13 \pm 3.59)$ respectively. The above result suggests that aqueous extract of $P$. africanum saw-dust powder has piscicidal property and is highly toxic to C.gariepinus. Therefore, care should be taking in the use of $P$. africanumtoxicant under fish culture conditions except for pond cleansing of unwanted aquatic fauna before stocking and fish killed with this toxicant should be totally avoided for human consumption as this can induce long term health hazard on the internal organs of the consumer.
\end{abstract}

Keywords: Clarias gariepinus; Haematological; Piptadeniastrum africanum; Toxicity; Water Quality

\section{Introduction}

Piptadeniastrum africanumfamily leguminosea, Genus Piptadeniastrunm, is a large buttress tree of about $50 \mathrm{~m}$ or more in height has leaflets which are alternate and bipinnately compound. The leguminosae are mostly tropical and subtropical trees and shrubs comprising about 40 genera and 2000 species, the tree sprouts freeing from the stump, the sapwood when fresh is pale reddishyellow or pinkish- white and comparatively wide. The tree is variously called as "Kiryar Kurmi" in Hausa "Ofie" in Igbo and "Agboni or Agboyin" in Yoruba[1].
Most fish poison also called Icthyotoxins (piscicidal) has been identified in related plant species, a variety of phytochemicals found in these plant will stun fish when it passes through the gills or in some cases when ingested making the fish to float to the surface for essay capture OECD (2001)[2]. Since prehistoric times various cultures throughout the world have used piscicidal plants for fishing, plants are generally regarded as inexhaustible sources of structurally diverse and biologically active substance [3]. Fossil record dates back the use of plant by man for various purposes including medicinal use [4-6]; however, their use as poison for obtaining fish from water bodies is of great concern because of their adverse effect on the aquatic organism especially fish.

The clariids are the most suitable species for aquaculture in 


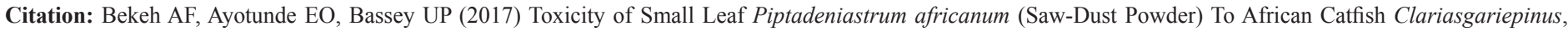
Adult. J Fish Aqua Dev: JFAD-116.

African since 1970, it has been considered to hold great promise for fish farmers in Africa [7]. The large Africa species of catfish contain two popular genera Clarias and Heterobranchus. There are ecologically important and commercially valued fishes for the $\mathrm{Ni}$ geria fishery and aquacultural industry. They are potamodromous fishes that migrate within streams and rivers [8]. These fish constitute the largest group of cultured species after carp, solmonid and Tilapia, and it grows well under various culture systems of the world in these areas, they are extremely popular an account of their testy flesh, unparalleled hardness, rapid growth and high market price (FAO 2003).Clarias gariepinusoccupies a unique and prominent position in the commercial fisheries in Nigeria because it is testy hardy, tolerating poor water quality conditions. It is also capable of reproducing in captivity and growing to a size of $7.0 \mathrm{~kg}[9,10]$. These are various methods to capture fish from water; these include the use of hooks, nets, fishing traps with baits, use of chemicals substance and the use of plants and plant products. These methods seen cheap and affordable hence commonly practiced by fisher folk all over the world.

Although the piscicidal potentials of Piptadeniastrum africanumis generally known among local fisher folk, there is no report on the toxicity of Piptadeniastrum africanumsaw-dust power to Clarias gariepinus adult. This effect on the fish is directly proportional to the toxicant concentration, which may have long time adverse effect on the consumers $[11,12]$. Therefore, the use of this toxicant in aquatic environment needs proper control to avoid reduction in fish population especially Clariassppand non- targeted aquatic fauna.This work determined the normal dosage of Piptadeniastrum africanumto adult Catfish Clarias gariepinusand its effect on water quality, through the determination of toxicity and tolerance level.

\section{Materialsand Methods}

\section{Collection of the Fish}

500 adult Clarias gariepinus, with the mean body weight $(\mathrm{g})$ and total length $(\mathrm{cm})$ of $86.01 \pm 12.10 \mathrm{SD}$ and $20.91 \pm 2.0 \mathrm{SD})$ as presented in table 8, were procured from Songhai fish farm, Itigidi, Abi LGA Cross River State. The fish was transported in two (2) aerated plastic bowl to the Department of Fisheries and Aquatic science wet Laboratory Cross River University of Technology, Obubra, Cross River State, Nigeria.

\section{Acclimation}

In the laboratory the fish were acclimated for seven (7) days in a large holding rubber tank half filled with DE chlorinated water.During the acclimation period, the fish were fed twice a day with a feed containing $35 \%$ crude protein at $1 \%$ biomass, and the used water was renewed every two days. Feeding was discontinued $24 \mathrm{hrs}$ before the commencement of the experiment, to minimize the contamination of the test aquaria.

\section{Collection of Plant Materials}

Freshly sawn saw-dust of Piptadeniastrum africanumwere collected from a farm in Boki Local Government Area Cross Riv- er State, Nigeria, where a timber dealer was sawing, the tree was identified using taxonomy key of [1], before collection and was sun dried for three days. The dried saw-dust were sieved with a mosquito net mesh size to obtain a fine powder, the fine powder obtained was stored in a dry airtight container.

\section{Preparation of Aqueous Extract and Range Finding Test}

Preliminary range finding test was conducted to determine the toxicity level of $P$. africanum saw-dust powder using standard procedure following the method of Olaifa,et al. (2003)[13]. A stock solution of $1000 \mathrm{ml} / \mathrm{L}(1 \mathrm{~g} / \mathrm{L})$ of $P$. africanumsaw-dust powder was prepared by adding $1.0 \mathrm{~g}$ of $P$. africanum in distilled water. A $15 \mathrm{~g}$ P.africanumsaw-dust powder was dissolved in 15 liters of distilled water to obtain a stock solution of $15 \mathrm{ml} / \mathrm{L}$ of the material. Triplicate seven (7) test concentrations were used for this investigation: one control and six tests solutions of $P$. africanum saw-dust powder in triplicates $C$. gariepinus adults were batch-weighed with a top-loading Mettler balance (Mettler Toledo K), and distributed randomly in triplicate per treatment. The plastic aquaria tanks were covered with perforated covers to prevent fish jumping out; there was no aeration, no water change, no feeding for 24 hours before and during the investigation. The toxicant was introduced at concentrations $10,20,30,40$, and $50 \mathrm{mg} / 1$ with a control $0 \mathrm{mg} / 1$. The behavior and mortality of the test fish in each tank was monitored for $24 \mathrm{~h}$ and recorded every hour.

\section{Definitive Test}

Definitive test was conducted using triplicate concentrations of $0 \mathrm{mg} / 13.3,6.6,9.9,13.2,16.5$ and $19.8 \mathrm{mg} / \mathrm{l}$ of $P$. africanumsawdust powder determined from the range finding test. Twenty-one plastic tanks were randomly labeled and each filled with 15 litres of water from Ovonum beach. The concentrations were prepared following [13] as mentioned in materials and methods. The mixture was stirred with a plastic metric ruler for homogeneous mixing. Within twenty-five minutes the tanks were randomly stocked with 10 adult of $C$. gariepinus each using aquarium net. Fish mortality was monitored and recorded hourly for the first four hours, every $4 \mathrm{~h}$ for the next $24 \mathrm{~h}$, and subsequently every $24 \mathrm{~h}$, for the next $96 \mathrm{~h}$. The inability of fish to respond to external stimuli was used as an index of death. Apart from monitoring and recording fish mortality, the fish behavior such as erratic swimming, air gulping and loss of reflex was monitored.

\section{Water qualities Parameters}

The water quality parameters were recorded for temperature, dissolved oxygen (Do) content, $\mathrm{pH}$ and conductivity before and after the experiment. $\mathrm{pH}$ was determined using a digital $\mathrm{pH}$ meter (Mettler Toledo 320). DO and conductivity were measured using a digital dissolved oxygen meter (oxygen analyzer model JPB-607 portable) once in a day at 8.00am.

\section{Experimental Design and Data collection}

The experiment was Completely Randomized Design each of the treatment level had three replicates.Behavioral responses such as initial distress of swimming movements, loss of balance, 


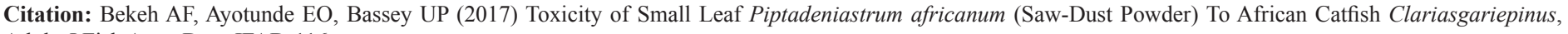
Adult. J Fish Aqua Dev: JFAD-116.

incessant gulping of air and fish setting at the bottom of the aquaria motionless with slow opercula movement.Dead fish were removed immediately to prevent polluting the test medium and failure of the fish to respond to stimuli from a push with a plastic metric ruler was used as an indicator of death.

\section{Haematological Parameters}

At the end of the experiment, blood samples (3-5ml/fish) were collected from the fish after $96 \mathrm{hrs}$ exposure period by the use of disposable hypodermic syringe and $5 \mathrm{ml}$ needles. The collected blood was stored EDTA. The haematological analysis of fish followed the method described by Svobodova,et al. (1999)[14]. The blood samples were analyzed for Packed Cell Volume (PCV), Red Blood cell (RBC), White Blood cell (WBC) Hemoglobin (Hb).

\section{Methods of Statistical Analysis}

Data obtained from the experiments were subjected to analysis of variance (ANOVA) test using statistical package for the social sciences (SPSS) version 18 where differences exist. Duncan Multiple Range Test separated them and F- test used for significant differences $(p<0.05)$ between the various treatments. An analysis of the Lethal Concentrations (LC) values for the 12, 24, 48, 72 and 96 hours and the associated confidence level of $95 \%$ of $P$. africanum were done with (Graphical) Probit analysis.

\section{Results}

\section{Toxicity}

The 96hours $\mathrm{LC}_{50}$ of an aqueous extract of $P$. africanumtoClarias gariepinusadult is presented in(Table 1) and (Figure 1).

\begin{tabular}{|c|c|c|c|}
\hline S/N & TIME(Hrs) & LC50 & MATC (mg/l) \\
\hline 1 & 24 & 9.9 & $0.99-0.099$ \\
\hline 2 & 48 & 6.6 & $0.66-0.066$ \\
\hline 3 & 72 & 3.3 & $0.33-0.033$ \\
\hline 4 & 96 & 3.3 & $0.33-0.033$ \\
\hline
\end{tabular}

Table 1: The LC50values of Clarias garienpinus Adult.

This value is the concentrations of the treatments required to bring about $50 \%$ mortalities of Clarias gariepinusadult within 96hours periods. The acute toxicity of $\mathrm{P}$. africanum decreased with increase in time. Total mortality resulted at concentration of $19.8 \mathrm{mg} / \mathrm{l}$ ofP. africanumto adult Clarias gariepinusand it was observed that the fish showed differences in tolerance level to the toxicants of $\mathrm{P}$. africanum. The maximum admissible toxicant concentration of $0.33 \mathrm{mg} / 1-0.033 \mathrm{mg} / 1$ established for adult Clarias gariepinusderived by multiplied the $96 \mathrm{hLC} 50$ with an application factor of between 0.1-0.01according to Koesoemadinata.

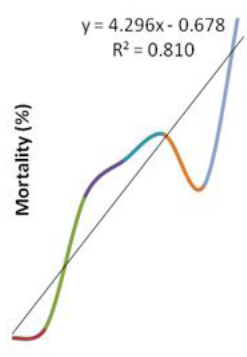

Concentration $(\mathrm{mg} / \mathrm{l})$

24hrs

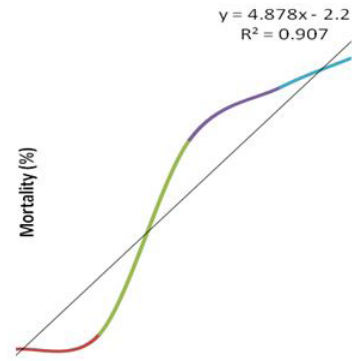

Concentration $(\mathrm{mg} / \mathrm{l})$

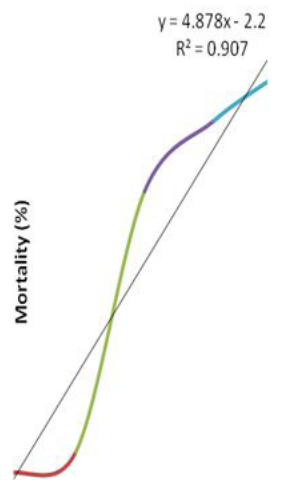

Concentration (mg/l)

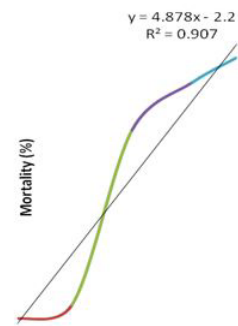

Concentration $(\mathrm{mg} / \mathrm{l})$ 28hrs

$72 \mathrm{hrs}$

Figure 1: Graph showning the method of LC50using (Graphical) Probit Analysis.

\section{Water quality parameters}

The mean water quality parameter of temperature, dissolved oxygen, $\mathrm{pH}$ and conductivity of the various concentrations did not vary significantly $(\mathrm{P}<0.05)$ from those of control. The mean value recorded for the various concentrations were similar to those of the control in both Range Finding Test and Definitive Test. See (Table 2). 
Citation: Bekeh AF, Ayotunde EO, Bassey UP (2017) Toxicity of Small Leaf Piptadeniastrum africanum (Saw-Dust Powder) To African Catfish Clariasgariepinus, Adult. J Fish Aqua Dev: JFAD-116.

\begin{tabular}{|c|c|c|c|c|c|c|c|c|c|}
\hline \multicolumn{5}{|c|}{ Range Finding Test } & \multicolumn{5}{|c|}{ Definitive Test } \\
\hline Concen & Temp(Oc) & $\mathrm{Ph}$ & Conduc. & $\mathrm{DO}(\mathrm{mg} / \mathrm{L})$ & Concen. & Temp (Oc) & $\mathrm{pH}$ & Conduc. & $\mathrm{DO}(\mathrm{mg} / \mathrm{L})$ \\
\hline To $(\mathrm{Omg} / \mathrm{L})$ & $25.00 \pm 0.00$ & $6.93 \pm 0.28$ & $48.00 \pm 5.29$ & $2.70 \pm 0.36$ & To $(\mathrm{Omg} / \mathrm{L})$ & $27.40 \pm 2.64$ & $6.76 \pm 0.23$ & $38.93 \pm 0.70$ & $4.03 \pm 0.89$ \\
\hline $\mathrm{T} 1(10 \mathrm{mg} / \mathrm{L})$ & $25.00 \pm 0.00$ & $6.96 \pm 0.49$ & $43.33 \pm 2.51$ & $2.76 \pm 0.40$ & $\mathrm{~T} 1(3.3 \mathrm{mg} / \mathrm{l})$ & $27.40 \pm 2.64$ & $7.56 \pm 0.57$ & $41.33 \pm 0.57$ & $3.03 \pm 0.05$ \\
\hline $\mathrm{T} 2(20 \mathrm{mg} / \mathrm{L})$ & $25.00 \pm 0.00$ & $7.26 \pm 0.11$ & $39.66 \pm 2.30$ & $3.23 \pm 0.57$ & $\mathrm{~T} 2(6.6 \mathrm{mg} / \mathrm{L})$ & $28.50 \pm 0.40$ & $7.76 \pm 0.25$ & $41.66 \pm 0.57$ & $3.20 \pm .10$ \\
\hline $\mathrm{T} 3(30 \mathrm{mg} / \mathrm{L})$ & $25.00 \pm 0.00$ & $7.53 \pm 0.32$ & $41.33 \pm 3.05$ & $3.63 \pm 0.28$ & T3 (9.9mg/L) & $29.40 \pm 0.30$ & $7.60 \pm 1.38$ & 4.002 .00 & $3.30 \pm 0.20$ \\
\hline $\mathrm{T} 4(40 \mathrm{mg} / \mathrm{L})$ & $25.00 \pm 0.00$ & $7.30 \pm 1.32$ & $44.66 \pm 5.86$ & $3.36 \pm 0.40$ & $\mathrm{~T} 4(13.2 \mathrm{mg} / \mathrm{L})$ & $29.30 \pm 0.52$ & $8.46 \pm 0.05$ & $43.33 \pm 3.78$ & $3.56 \pm 0.20$ \\
\hline T5 (50mg/L) & $25.00 \pm 0.00$ & $6.86 \pm 2.90$ & $28.00 \pm 15.87$ & $4.73 \pm 0.68$ & T5 (16.5mg/L) & $29.23 \pm 0.28$ & $8.53 \pm 0.05$ & $46.33 \pm 0.57$ & $3.73 \pm 0.60$ \\
\hline & T6 (19.8mg/L) & $29.23 \pm 028$ & $8.53 \pm 0.05$ & $46.33 \pm 0.57$ & $3.73 \pm 0.60$ \\
\hline
\end{tabular}

Table 2: Summary of water quality parameter of $P$. africanum to Clarias gariepinus (mean $\pm \mathrm{SD})$.

\section{General Behavioral Changes}

Fish showed initial distress swimming movements, loss of balance, incessant gulping of air and fish settling at the bottom of aquarium motionless with slow opercula movement. There was no serious change in fish Clarias gariepinus behavior in the lower concentration $(3.3$ and $6.6 \mathrm{mg} / \mathrm{l})$ for the first $24 \mathrm{hr}$ of exposure to P. africanum. The abnormal behavior displayed by the fish increased with an increase in concentration of P. africanumin water but increased with an increase in time of exposure. See (Table 3 and Table 4).

\begin{tabular}{|c|c|c|c|c|}
\hline Behavior/exposure time & 6hrs & 12hrs & 24hrs & 48hrs \\
\hline Concentration $(\mathrm{mg} / \mathrm{L})$ & $0,10,20,30,40,50$ & $0,10,20,30,40,50$ & $0,10,20,30,40,50$ & $0,10,20,30,40,50$ \\
\hline Air gulping & -+++++ & -+++++ & -+++++ & -+++++ \\
\hline Erratic swimming & --+++ & ---+++ & --++++ & --++++ \\
\hline Loss of balance & $-\ldots+$ & ---+++ & ---+++ & --++++ \\
\hline Excessive mucus secretion & $-\ldots-\ldots$ & $-\ldots-\ldots$ & ---+++ & --++++ \\
\hline Operculum movement & $-\ldots$ & $-\ldots-+$ & ---+++ & --++++ \\
\hline Tail movement & $-\ldots$ & $-\ldots$ & ---++ & ---+++ \\
\hline Molting & - - - - - & - - - - - & - - - - - & $-\ldots---$ \\
\hline Discoloration & $-\ldots-$ & $-\ldots$ & ---++ & --++++ \\
\hline Barbell deformation & $-\ldots-$ & $-\ldots$ & $-\ldots$ & $-\ldots-$ \\
\hline $\begin{array}{c}\text { present } \\
\text { Not pres }\end{array}$ & & & & \\
\hline
\end{tabular}

Table 3: General behavioral changes of Clarias gariepinusexposed to different concentration of aqueous extract of $P$. africanum(range finding test)

\begin{tabular}{|c|c|c|c|c|}
\hline Behavior/exposure time & 24hrs & $48 \mathrm{hrs}$ & $72 \mathrm{hrs}$ & 96hrs \\
\hline Concentration (mg/L) & $0,3.3,6.6,9.9,13.2,16.5,19.8$ & $0,3.3,6.6,9.9,13.2,16.5,19.8$ & $0,3.3,6.6,9.9,13.2,16.5,19.8$ & $0,3.3,6.6,9.9,13.2,16.5,19.8$ \\
\hline Air gulping & ---+++ & --+++++ & -++++++ & -++++++ \\
\hline Erratic swimming & $-\ldots-++$ & $-\ldots+++$ & -++++++ & --++++- \\
\hline Loss of balance & $-\ldots \ldots$ & $-\ldots \ldots$ & $\ldots \ldots$ & $-\ldots \ldots$ \\
\hline $\begin{array}{c}\text { Excessive mucus secre- } \\
\text { tion }\end{array}$ & $-\ldots$ & $-\ldots+++$ & $-\cdots+++$ & $-\ldots+++$ \\
\hline Operculum movement & $-\ldots-\ldots$ & $-\ldots-\ldots+$ & $-\ldots+--$ & $--++\ldots$ \\
\hline Tail movement & ---+++- & ---++-- & $-\ldots++-$ & $-\ldots+++$ \\
\hline Molting & $\ldots \ldots$ & $\ldots \ldots$ & $\ldots \ldots$ & $\ldots \ldots$ \\
\hline Discoloration & $-\ldots-\ldots$ & $-\ldots-\ldots$ & $-\ldots-++$ & ---+++ \\
\hline Barbell deformation & $\ldots \ldots$ & $\ldots \ldots$ & $\ldots \ldots$ & $-\ldots \ldots$ \\
\hline
\end{tabular}




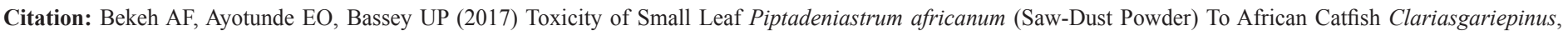
Adult. J Fish Aqua Dev: JFAD-116.

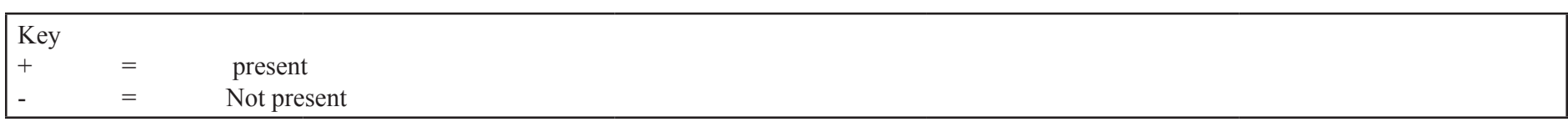

Table 4: General behavioral changes of Clarias gariepinusexposed to different concentration of aqueous extract of $P$. africanum(Definitive test).

\section{Mortality}

Changes in mortality is due to the interaction between exposure levels of the toxicant at the different time intervals was narrowest at the $24 \mathrm{hr}$ becoming more variable with an increase in time, there was mortality in treatment T1-T6. There was no mortality recorded in the control. See (Table 5 and Table 6).

\begin{tabular}{|c|c|c|c|c|c|c|c|c|c|c|c|c|}
\hline Test Conc. (mg/L) & 15 mins & 30 mins & $45 \mathrm{mins}$ & $1 \mathrm{hrs}$ & $2 \mathrm{~h}$ & $3 \mathrm{~h}$ & $4 \mathrm{~h}$ & $8 \mathrm{~h}$ & $12 \mathrm{~h}$ & $16 \mathrm{~h}$ & $20 \mathrm{~h}$ & 24 \\
\hline 0 & 0 & 0 & 0 & 0 & 0 & 0 & 0 & 0 & 0 & 0 & 0 & 0 \\
\hline 10 & 0 & 0 & 0 & 3 & 10 & 16 & 20 & 23 & 23 & 27 & 27 & 33 \\
\hline 20 & & 0 & 0 & 0 & 0 & 3 & 13 & 27 & 33 & 43 & 47 & 50 \\
\hline 30 & 0 & 0 & 10 & 30 & 50 & 60 & 60 & 60 & 60 & 67 & 73 & 83 \\
\hline 40 & 0 & 30 & 53 & 80 & 100 & 100 & 100 & 100 & 100 & 100 & 100 & 100 \\
\hline 50 & 0 & 30 & 77 & 100 & 100 & 100 & 100 & 100 & 100 & 100 & 100 & 100 \\
\hline
\end{tabular}

Table 5: Mean percentage cumulative mortality of $P$. Africanumto $C$. gariepinusadult (Range Finding).

\begin{tabular}{|c|c|c|c|c|c|c|c|c|c|c|c|c|}
\hline $\mathrm{Mg} / \mathrm{l}$ conc. & $1 \mathrm{hr}$ & $2 \mathrm{hr}$ & $3 \mathrm{hr}$ & $4 \mathrm{hr}$ & $8 \mathrm{hr}$ & $12 \mathrm{hr}$ & $16 \mathrm{hr}$ & $20 \mathrm{hr}$ & $24 \mathrm{hr}$ & $48 \mathrm{~h}$ & $72 \mathrm{~h}$ & $96 \mathrm{~h}$ \\
\hline 0 & 0 & 0 & 0 & 0 & 0 & 0 & 0 & 0 & 0 & 0 & 0 & 0 \\
\hline 3.3 & 0 & 0 & 0 & 0 & 0 & 0 & 0 & 0 & 3 & 6 & 16 & 33 \\
\hline 6.6 & 0 & 0 & 0 & 3 & 3 & 13 & 16 & 33 & 40 & 57 & 70 & 73 \\
\hline 9.9 & 0 & 0 & 3 & 6 & 10 & 23 & 33 & 37 & 50 & 60 & 67 & 70 \\
\hline 13.2 & 0 & 3 & 6 & 6 & 10 & 27 & 33 & 50 & 57 & 63 & 77 & 77 \\
\hline 16.5 & 6 & 10 & 13 & 23 & 33 & 40 & 40 & 43 & 43 & 53 & 60 & 67 \\
\hline 19.8 & 0 & 10 & 23 & 60 & 67 & 87 & 97 & 100 & 100 & 100 & 100 & 100 \\
\hline
\end{tabular}

Table 6: Mean Percentage Cumulative Mortality of P. africanumto Clarias gariepinus Adult (Definitive).

\section{Haematological parameters}

There was significant reduction $(\mathrm{P}<0.05)$ in the value of blood parameters of Clarias gariepinusadult after exposure to $96 \mathrm{hr}$ in aqueous extract of $P$. africanumsaw-dust powder (Table 7) white blood cell decreased from $1.72 \pm 4.93 \%$ in the control to $1.69 \pm 9.90 \%$ in test concentrations of 33.5 and $40.2 \mathrm{mg} / \mathrm{l}$ while Red blood cells decreased from $4.86 \pm 4.03$ in the control to $1.55 \pm 0.06 \%$ in test concentrations of 33.5 and $40.2 \mathrm{mg} / \mathrm{l}$. there was no increase in hematocrit from $13.33 \pm 1.52 \%$ to $21.76 \pm 0.40 \%$. Mean hemoglobin concentration reduced from $25.83 \pm 7.72$ in control to 30.00 \pm 2.82 . No significant difference was noticed in the Mean Cell Volume (MCV), hemoglobin and mean cell hemoglobin.

\begin{tabular}{|c|c|c|c|c|c|c|c|c|c|}
\hline $\begin{array}{l}\text { Conc. } \\
(\mathrm{mg} / \mathrm{L})\end{array}$ & $\begin{array}{l}\text { White blood } \\
\text { cell (ul)) }\end{array}$ & $\begin{array}{l}\text { Red blood } \\
\text { cell (ul) }\end{array}$ & $\begin{array}{l}\text { Hemoglo- } \\
\text { bin }(\mathrm{g} / \mathrm{dl})\end{array}$ & $\begin{array}{c}\text { Hematocrit } \\
(\%)\end{array}$ & $\begin{array}{c}\text { Mean cell } \\
\text { volume (fl) }\end{array}$ & $\begin{array}{l}\text { Mean cell He- } \\
\text { moglobin (pg) }\end{array}$ & Platelet (ul) & $\begin{array}{l}\text { Lympho- } \\
\text { cytes (ul) }\end{array}$ & $\begin{array}{l}\text { Mean cell Hemoglo- } \\
\text { bin concentration. }\end{array}$ \\
\hline 0 & $1.72 \pm 4.93$ & $4.86 \pm 4.63$ & $4.03 \pm 3.43$ & $13.33 \pm 1.52$ & $1.41 \pm 12.49$ & $36.23 \pm 10.08$ & $34.66 \pm 25.79$ & $1.58 \pm 13.19$ & $25.83 \pm 7.72$ \\
\hline 3.3 & $1.60 \pm 4.00$ & $1.26 \pm 0.08$ & $5.13 \pm 0.66$ & $17.80 \pm 2.87$ & $1.40 \pm 18.30$ & $40.43 \pm 2.98$ & $27.66 \pm 10.26$ & $1.53 \pm 4.79$ & $28.96 \pm 1.89$ \\
\hline 6.6 & $1.68 \pm 19.50$ & $1.45 \pm 0.22$ & $6.26 \pm 1.02$ & $20.36 \pm 1.56$ & $1.41 \pm 13.40$ & $42.50 \pm 0.40$ & $25.66 \pm 12.85$ & $1.62 \pm 18.05$ & $30.00 \pm 2.82$ \\
\hline 9.9 & $1.63 \pm 20.99$ & $1.41 \pm 0.23$ & $5.83 \pm 1.23$ & $20.26 \pm 3.63$ & $1.47 \pm 3.29$ & $41.00 \pm 3.03$ & $20.66 \pm 15.17$ & $1.58 \pm 19.27$ & $27.76 \pm 1.44$ \\
\hline 13.2 & $1.62 \pm 33.34$ & $1.24 \pm 0.28$ & $5.06 \pm 1.40$ & $18.66 \pm 4.66$ & $1.49 \pm 3.98$ & $40.46 \pm 2.05$ & $18.00 \pm 16.64$ & $1.53 \pm 28.33$ & $26.96 \pm 1.05$ \\
\hline 16.5 & $1.69 \pm 9.90$ & $1.55 \pm 0.06$ & $6.20 \pm 0.10$ & $21.76 \pm 0.40$ & $1.40 \pm 3.30$ & $39.93 \pm 1.00$ & $9.66 \pm 3.21$ & $1.69 \pm 1.22$ & $28.50 \pm 0.10$ \\
\hline 19.8 & $1.69 \pm 10.28$ & $1.55 \pm 0.06$ & $6.20 \pm 0.10$ & $21.76 \pm 0.04$ & $1.40 \pm 3.30$ & $39.93 \pm 1.00$ & $10.13 \pm 3.58$ & $1.70 \pm 1.65$ & $28.50 \pm 0,10$ \\
\hline
\end{tabular}

Table 7: Mean Percentage Cumulative Mortality of P. africanumto Clarias gariepinus Adult (Definitive). The summary of toxicity of P. africanumaqueous extract on haematological parameters Clarias gariepinusadult (mean $\pm \mathrm{SD}$ ). 


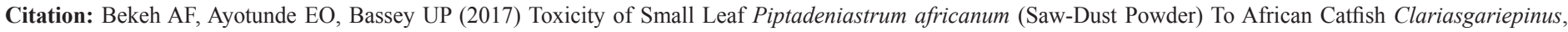
Adult. J Fish Aqua Dev: JFAD-116.

\begin{tabular}{|c|c|c|c|c|c|}
\hline conc. Range finding test & Weight $(\mathrm{g})$ & Standard length $(\mathrm{cm})$ & conc. Definitive test & Weight & Standard length $(\mathrm{cm})$ \\
\hline $0.00 \mathrm{mg} / \mathrm{L}$ & $87.30 \pm 5.45$ & $21.57 \pm 2.59$ & $0.00 \mathrm{mg} / \mathrm{L}$ & $101.77 \pm 6.27$ & $21.72 \pm 0.53$ \\
\hline $10 \mathrm{mg} / \mathrm{L}$ & $90.04 \pm 11.42$ & $21.77 \pm 0.50$ & $3.3 \mathrm{mg} / \mathrm{L}$ & $73.94 \pm 12.36$ & $22.00 \pm 0.72$ \\
\hline $20 \mathrm{mg} / \mathrm{L}$ & $92.44 \pm 4.24$ & $22.13 \pm 0.90$ & $6.6 \mathrm{mg} / \mathrm{L}$ & $85.05 \pm 9.59$ & $21.57 \pm 0.37$ \\
\hline $30 \mathrm{mg} / \mathrm{L}$ & $83.17 \pm 1.58$ & $21.22 \pm 0.32$ & $9.9 \mathrm{mg} / \mathrm{L}$ & $77.33 \pm 16.65$ & $22.35 \pm 1.82$ \\
\hline $40 \mathrm{mg} / \mathrm{L}$ & $83.17 \pm 1.58$ & $21.22 \pm 0.32$ & $13.2 \mathrm{mg} / \mathrm{L}$ & $81.05 \pm 16.66$ & $20.67 \pm 0.55$ \\
\hline $50 \mathrm{mg} / \mathrm{L}$ & $78.11 \pm 18.93$ & $19.96 \pm 1.15$ & $16.5 \mathrm{mg} / \mathrm{L}$ & $77.00 \pm 15.50$ & $20.50 \pm 1.19$ \\
\hline $60 \mathrm{mg} / \mathrm{L}$ & $78.11 \pm 18.93$ & $19.96 \pm 1.15$ & $19.8 \mathrm{mg} / \mathrm{L}$ & $77.00 \pm 15.50$ & $20.50 \pm 1.19$ \\
\hline
\end{tabular}

Table 8: Length-weight relationship of Clariasgariepinus.

\section{Discussion}

The result of the physio-chemical parameters in the different treatments showed no significant difference from control. The water quality parameter recorded before, during and after the experiment were within the acceptable range for toxicity test (APHA, 1998) [15]However, the fluctuations with significant difference might have been altered by the introduction of aqueous extract of $P$. africanumand hence produced deleterious effect such as stressful conditions of abnormal behaviors prior to death and mucus secretions on the gills of the fish. This result is similar to the study done by Onusiriuka and Ufodike (1994)[16] that exposed Clariasgariepinusto Akee apple and sausage plant extracts and reported no significant difference $(\mathrm{P}<0.05)$ in the water quality parameter analyzed. But not similar with the work of Health who reported changes in haematological parameters and swimming activity of fish due to changes inwater quality parameters [17]. The result obtained from this work compared favorably with those reported by Ayotunde and Offem (2005) [18] and Ayotunde and Offem (2008) [12] and Auta et al., (2004)[19], who reported that the results of water quality parameters $(\mathrm{pH}$, Temperature, and Dissovled Oxygen) obtained for the test solution during alltheir experiments were not significantly different $(\mathrm{p}<0.05)$ from the control.

\section{Behavioral Responses}

The result obtained from these studies revealed that fish exposed to aqueous extract of $P$. africanum saw-dust powder on the behavior of Clarias gariepinususually exhibits some behavioral changes such as vigorous movement, air gluping, erratic swimming, operculum and tail movement, and loss of balance.These observations agree with the report of when Nile tilapia (Oreochromis niloticus) was exposed to aqueous extract of dry tobacco dust (Nicotiana tobaccum) the fish exhibited stressful behavior such as erratic spiral movement and showed signs of respiratory distress suggesting that the reaction exhibited by $O$. niloticusmight have been induced by the stimulant of nicotine present in the tobacco extract [20] also reported that the skin of the experimental fish became darker in colour with the display of signs of respiratory distress with increased opercula movement [21]. This result also compared favorably with the work ofAyotunde EO (2006)[22], when Afri- can catfish (C.gariepinus) was exposed to Parkiabiglobossa and Raphiavinefera extracts and catfish hybrid fingerlings treated with cassava effluents. Increased in concentrations of aqueous extracts of $P$ africanum led to increased OBF, TBF and [23]mortality as was also similarly observed in $C$. gariepinus exposed to aqueous extracts of [16] reported that the active ingredients present in the members of the family Leguminosae to which $P$. africanum belongs include saponins, alkaloids, tannins and resins. Kritzonreported that alkaloids toxin belongs to a group called flavonoids which stun fish by impairing their oxygen consumption, and the presence of saponins acts on respiratory organs of the fish. The aqueous extract of $P$. africanum contains alkaloids and saponins and therefore could have caused the same reaction as observed by Kritzon. This may explain the various responses of the C.gariepinus used in this study to the presence of various concentrations of the stimulant present in the plant extract. The signs showed by the experimental fish in the study are clear indications that mortality of the exposed fish may have been due to the impaired respiratory activity.Fafioye reported similar changes in the fish exposed to Parkia bioglobosa and Raffia vinifera. Alkahem also reported similar observation on Oreochromis niloticus exposed to trichloroform while Omotoyin et al., (1999) [24]reported similar observation with Sarotherodon galilaeus(Tilapia) fingerlings exposed to piscicidal plants extract of Tetrapleuratetraptera. The high level of mortality of the fish treated with different concentrations of the aqueous extract of $P$. africanumhas confirmed that $P$. africanumis a plant with piscicidal properties due to its ability to kill fish even at a very low concentration $3.3 \mathrm{mg} / \mathrm{l}$.

\section{Haematological parameter}

The changes in the value of blood parameters of $C$. gariepinusadult after exposure to $96 \mathrm{hrs}$ in the aqueous extract of $P$. africanumsaw dust powder in this experiment is similar to the result obtained by Ayotunde,et al.(2010) [25] who reported the absence of significant changes in RBC counts, hematocrit value, hemoglobin content and the blood indices (MCHC, MCV, and $\mathrm{MCH}$ ) and the significant increases of the WBC counts and lymphocytes percentage with the decrease in blood platelets. However, Omoniyiet, al.(2002) [20]noted that water quality variables produced negligible effects on the blood of $C$. gariepinus exposed to lethal 


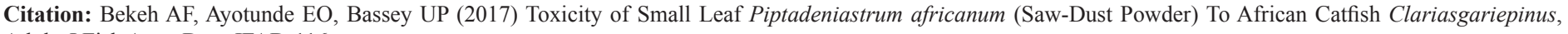
Adult. J Fish Aqua Dev: JFAD-116.

and sub lethal concentration of tobacco leaf extracts. They were significant changes in $\mathrm{WBC}, \mathrm{RBC}, \mathrm{Hb}, \mathrm{MCH}$, from the control. And the $\mathrm{RBC}$ and platelet count of the treated fish are lower than the control. This observation could suggest possible reason for the irrational behavior, restlessness, and the subsequent mortality observed in the experimental fish. The result from this study suggest that the aqueous extracts of $P$. africnummay have impaired oxygen transport and impacted negatively on the defense mechanism of the exposed fish evidenced by a reduction in WBC value, but enhanced clotting time (thrombocytosis) in the event of any vascular injury to the exposed fish. The value of $96 \mathrm{hrs} \mathrm{LC}_{50}$ of $0.33 \mathrm{mg} / 1$ reported in this study is much lower than Ayotunde, et al.(2010) [25] earlier reported from 0.1-1.29 mg/l. Also, lower than the result of Wade et, al.(2002) [21] who reported that 96hrs $\mathrm{LC}_{50}$ of $0.19 \mathrm{mg} / 1$ for Oreochromis niloticus fingerlings exposed to effluent of cassava (Manihot esculenta). And the $96 \mathrm{hrs} \mathrm{LC}_{50}$ of $0.59 \mathrm{mg} / \mathrm{l}$ reported by Okey, et al.(2009) is almost equal to the result of this study. The haematological examination shows decrease in a number of cell counts $\mathrm{WBC}, \mathrm{RBC}, \mathrm{Hb}, \mathrm{MCV}$, hematocrit lymphocytes with mean values $(1.61 \pm 4.01,1.23 \pm 0.09,5.13 \pm 0.67,1.40 \pm 18.30$, $17.80 \pm 2.88$ and $1.54 \pm 4.80)$ to $(1.70 \pm 10.29,1.55 \pm 0.07,6.20 \pm 0.10$, $1.40 \pm 3.30,21.77 \pm 0.40$ and $1.70 \pm 1.66)$. There was significant decrease in $\mathrm{MCH}, \mathrm{MCHC}$ and platelet with mean values $(40.43 \pm 2.93$, $28.97 \pm 1.89$ and $27.67 \pm 10.26)$ to $(39.93 \pm 1.00,28.50 \pm 0.10$ and $10.13 \pm 3.59)$ respectively.

The result in above blood parameters shows that the immune system may be compromised under exposure to the toxicant and plant derived toxins are known to cause changes in the blood variables ( $\mathrm{Hb} \mathrm{RBC} \mathrm{MCV}, \mathrm{MCH}$ and $\mathrm{MCHC}$ ) associated with oxygen transport in fish[20]. The absence of significant changes in WBC count, hematocrit value and the blood indices (MCHC, MCV and $\mathrm{MCH}$ ), and the significant increase of the RBC counts and Neutrophil percentage with the decrease in blood platelets agree with the findings in treated rat's species. The result in (Figure 1) indicates that the concentration of aqueous extract of Piptadenastrum africanum saw-dust powder influence the mortality of Clarias gariepinus adult by $81 \%$ as indicated in the $\mathrm{R}^{2}$ value of 0.810 when the concentration was applied at $24 \mathrm{hrs}$. Also at $48 \mathrm{hrs}$, the mortality rate was $91 \%$ as indicated in the $\mathrm{R}^{2}$ value of 0.907 as shown in figure 2. At $72 \mathrm{hrs}$ and $98 \mathrm{hrs}$ the concentrations coursed the same level of mortality as $48 \mathrm{hrs}, 72 \mathrm{hrs}$, and $98 \mathrm{hrs}$ respectively, as they all have $\mathrm{R}^{2}$ value of 0.907 . These findings indicate that the concentrations did not vary significantly when applied at $48 \mathrm{hrs}, 72 \mathrm{hrs}$, and $98 \mathrm{hrs}$ respectively revealing that there was no significant difference among treatments at $\mathrm{P}, 0.05$ level.

\section{References}

1. HutchinsonJ, DalzeilJM (1972) $2^{\text {nd }}$ Rev.Edition. Flora of West Tropical Africa. Millbank, London: 1-111.

2. OECD (2001) Organization of economic cooperation and development. Guidance document on aquatic toxicity testing of difficult substances and mixtures: 34-57.
3. OlatayoVS(2004) Studies of the effect of extracts from two local plants (Tephrosiavogeliiand parkiaclappertonian) on Clariasgariepinus (Teugel) in: Araoye, P. A. (ED). Proceedings of the $19^{\text {th }}$ Annual conference of the FISON. $16^{\text {th }}-20^{\text {th }}$ Nov: $128-135$.

4. SambasivamS, Karpagan G, Chandran R, Khan SA (2003) Toxicity of leaf extract of yellow Oleander Thevetianerifolia on Tilapia. J. Environ. Biol 24: 201-204.

5. Oti EE (2003) Acute toxicity of water extracts of bark of the neem plant Azadirachtaindica(lodd) to the African pike HepsetusOdoe (Bloch) in: Eyo A. An and Ayanda, j. O. (Eds). Proceedings of the $18^{\text {th }}$ Annual Conference of the FISON. Owerri: 22-27.

6. Oti EE, Upkabi UH (2000) Acute toxicity of milk extract of Thevetia peruviannato African catfish (hubrids). Afr. J. of Sci. and Tech 1: 132138.

7. Legendre M, teugels GG, Cauty C, Albert B (1992) A comparative study on morphology growth rate and reproduction of Clariasgriepin us, Heterobranchuslongifillis and their reciprocal hybrid. J. Fish. Boil 40: 59-79.

8. Teugels GG(1984) The nomenclature of African Clariasgariepinus species used in Aquaculture. Aquaculture 38: 373-374.

9. Holden M, Reed W (1972) West African Nature Fresh Water Fishes: West African Nature aHandbooks London.

10. Babatunde MM, olademeji AA, balogun TK(2000) Acute toxicity of gramozone to Oreochromis niloticusin Nigeria. Water, Air and soil pollution 131:1-10.

11. Ufodike EB, Omoregie E (1994) acute toxicity of water extracts of barks of Balaniteaegyptiaca and Kigeliaafricanato Oreochromis niloticus $(\mathrm{L})$. Aquacult Fish Mgt 25: 875-879.

12. Ayotunde EO, Ofem BO (2008) Acute and chronic toxicity of pawpaw (Carica papaya) seed powder to nile tilapia (Oreochromisniloticus) (linne 1757). Adult Afr JBiotechnol 7: 2265-2274.

13. OlaifafE, Olaifa AK, Onwude TE (2003) lethal and sub-lethal effects of copper to the African catfish (Clariasgariepinus) Juveniles. African journal of Biomedical Research7: 65-70.

14. Svobodova Z, Llody R, Machova J, Vyusoda B (1993) Water quality and fish health. EIFACT Tech. Paper No 54 Rome FAO: 59.

15. APHA (1998) American public health association standard method for examination of water and wastewater. $13^{\text {th }}$ Edition. ALPHA Washington DC USA: 1254.

16. Onusiriuka BC, Ufodike FB (1998) Growth of African catfish, Clariasgariepinus(Teugals) subjected to sub-lethal concentrations of water extract of Akee apple, Blighiasapidaand Sausage plant, Kigeliaaricana. Journal of Aquatic Sciences 13:59-62.

17. Adeyemo OK,Akintoye OA, Oghi ML (2004) Acute toxicity of chlorpyrifos (Dursban) to Clariasgariepinus Juveniles. Trop22: 4-8.

18. Ayotunde EO,Ofem BO (2005) Acute and chronic toxicity of pawpaw (Carica papaya) seed powder to nile Tilapia Oreochromis niloticus(Linne 1757) fingerlings. J. Agric. Technol. Environ 1:1-4.

19. Auta J, Balogun JK, Lawal fA, IpinjolujK (2004) Acute toxicity of the insecticides, Dimethoate on juveniles of Oreochromis niloticus (Trewavas) and Clariasgariepinus(Teugels). Journal of Aquatic sciences 19: 5-8. 
Citation: Bekeh AF, Ayotunde EO, Bassey UP (2017) Toxicity of Small Leaf Piptadeniastrum africanum (Saw-Dust Powder) To African Catfish Clariasgariepinus, Adult. J Fish Aqua Dev: JFAD-116.

20. Omoniyi I, Agbon AO, Sodunke SA (2002) effect of lethal and sublethal concentration of tobacco (Nicotiana tobaccum) lead dust extract on weight and Hematological changes in Clariasgariepinus(Burchell). Journal of Applied sciences \&Environmental management 6: 37-41.

21. Wade JW, Omoregie E, Ezenwaka (2002) Toxicity of cassava (Manihotesculenta CRANTS) effluent on the Nile Tilapia Oreochromis niloticus (I) Under laboratory condition. AJOL J Aqua Sci: 17.

22. Ayotunde EO (2006) Acute toxicity of moringa oleifera(drum stick) to Oreochromis niloticuusand Clariasgariepinus Ph.D. thesis FUTA 170.
23. Oti EE (2002) Acute toxicity of cassava mill effluent to the African catfish fingerlings. J. Environ. Biology: 20: 112-117.

24. Omitoyin BO, Ajani EK, Fajimi OE (1999) Toxicity of Gramoxone (Paraquat) to juvenile African catfish, Clariasgariepinus (Buchell,1822). American Euroasian Journal of Agricultural and Environmental Sciences 1: 26-30.

25. Ayotunde EO, Fagbero OA, Adebayo O (2010) Toxicity of aequeousextrct of Moringa oleiferaseed powder to Nile tilapia Oreochromis niloticus(Linne, 1779) fingerlings. International Research Journal of Agricultural Science 1: 142-150. 